IJCCS, Vol.9, No.1, January 2015, pp. 43 52

\title{
Sistem Multiagen untuk Pengklasteran Pendaki Menggunakan K-Means
}

\author{
Maya Cendana*1 dan Azhari S.N. ${ }^{2}$ \\ ${ }^{1}$ Mahasiswa Program Pascasarjana Ilmu Komputer, FMIPA, UGM, Yogyakarta \\ ${ }^{2}$ Staf pengajarProgram Pascasarjana Ilmu Komputer, FMIPA, UGM, Yogyakarta \\ e-mail: *1'maya.cendana@gmail.com, ${ }^{2}$ arisn.softcomp@gmail.com
}

\begin{abstract}
Abstrak
Para pendaki pemula sebaiknya melakukan pendakian gunung secara berkelompok, namun metoda pengelompokan secara manual yang sedang berjalan saat ini tidak efektif dan efisien, terutama bagi para pendaki solo yang tidak memiliki komunitas pendakian gunung. Oleh karena itu perlu dibangun sebuah media online yang mampu mengelompokkan para pendaki gunung secara otomatis.Pengelompokan dilakukan dengan algoritma klastering $K$ Means berbasis agen cerdas. Agen-agen tersebut akan berkolaborasi dalam proses negosiasi menentukan anggota klaster yang memiliki kesamaan kriteria. Keuntungan utama dari pemanfaatan multiagen ini adalah proses pengklasteran dilakukan secara multithread. Agenagen yang terlibat adalah agen user, agen basisdata, agen klastering, dan agen validasi. Agenagen tersebut dibangun di atas platform JADE dengan bahasa komunikasi FIPA ACL. Evaluasi dilakukan terhadap 10, 100 dan 200 data dengan jumlah klaster tententu untuk menghitung nilai kohesi/kepadatan dalam 1 klaster dan jarak pisah antar-klaster. Metrik pengukuran yang digunakan adalah WGAD dan BGAD. Hasil yang diperoleh adalah kualitas anggota klaster yang lebih baik dibandingkan k-means biasa.
\end{abstract}

Kata kunci: agen, jade, fipa acl, wgad, bgad

\begin{abstract}
The beginner climbers should do mountain climbing as a group, however, manually grouping method that is currently running is not effective and efficient, especially for the solo climber who do not have the mountaineering community. Therefore, it is necessary to build an online media that is able to classify mountaineers automatically. The grouping is done by the algorithm K-Means clustering -based intelligent agents. The agents will collaborate in the negotiation process and determines the cluster members that have similar criteria. The main advantage of using multiagentsis multithreading proces, so the clustering process will run at once. The agentsconsists of the user agent, the database agent, clustering agents, and validation agent. The agents are implemented with JADE platform because JADE is using FIPA ACL communication language. Evaluation will calculate the value of cohesion / density in one cluster and inter - cluster separation distances with 10,100 and 200 data. Metric measurement used are WGAD and BGAD. Thequality of a cluster member is better than using an usual k-means .
\end{abstract}

Keywords: agen, jade, fipa acl, wgad, bgad 


\section{PENDAHULUAN}

$M$ ountaineering atau kegiatan alam bebas yang berlokasi di wilayah pegunungan merupakan salah satu bentuk ekowisata yang digemari di Indonesia. Salah satunya adalah pendaian gunung. Umumnya, pendakian gunung bisa dilakukan secara solo, namun hal itu tidak dianjurkan bagi para pendaki pemula karena tingkat kesulitan dan kebutuhan kerja tim yang tinggi $[1,2,3]$.Saat ini, pengelompokan para pendaki masih dilakukan secara manual. Oleh karena itu, penelitian ini mengusulkan sebuah program komputer yang dapat melakukan pengelompokan para pendaki tersebut secara otomatis.

Metoda pengelompokan berdasarkan kriteria tersebut (klastering) akan menggunakan algoritma K-Means, namun algoritma K-Means juga memiliki beberapa kekurangan, terutama dalam proses pengklasteran itu sendiri karena hanya dapat mengeksekusi satu baris data per satu waktu. Salah satu cara mengatasi kekurangan tersebut adalah dengan menggunakan agen cerdas sebagai teknologi komunikasi yang memungkinkan terjadinya koordinasi antar-agen.Menurut hasil penelitian [4], gabungan agen-agen tersebut akan membentuk multiagen yang dapat melakukan negosiasi antar-agen (intra-agent negotiation) sehingga mampu meningkatkan hasil klastering. Multiagen yang akan dibangun terdiri dari agen user, agen klastering, agen basisdata dan agen validasi. Keempat agen tersebut akan berkolaborasi menghasilkan klaster terbaik dalam 2 proses. Proses pertama menghasilkan susunan inisial klaster yang baru, sedangkan proses kedua akan melakukan validasi terhadap hasil yang diperoleh dari proses pertama. Metoda validasi dilakukan dengan menghitung nilai kepadatan antar-obyek dalam klaster (cohesion value) dan jarak pemisah antar-klaster (separation value), yaitu dengan menggunakan metrik Within Group Average Distance (WGAD) dan Between Group Average Distance (BGAD).

Pemodelan untuk membangun multiagen tersebut adalah Agent UML yang sudah menjadi standar FIPA karena kemampuan komunikasinya yang baik, dan akan diimplementasikan dalam platform JADE. Pengiriman pesan dalam komunikasi JADE bersifat asinkronisasi sehingga pengolahan data akan jauh lebih cepat dibandingkan tanpa agen. Hasil akhir dari penelitian ini diharapkan dapat meningkatkan efektivitas hasil klastering dan dapat diterapkan dalam dunia pendakian secara nyata, serta dapat diimplementasikan pada kasus pengklasteran serupa

\section{METODE PENELITIAN}

\subsection{Pengumpulan Data}

Pengumpulan data dilakukan dengan 2 cara, yaitu studi kepustakaan dan survei.

\subsubsection{Studi Kepustakaan}

Studi kepustakaan dilakukan dengan mengumpulkan berbagai macam bahan referensi, seperti jurnal penelitian, tesis, disertasi, buku-buku teori dan sumber-sumber lain termasuk informasi yang diperoleh dari internet sebagai sumber data sekunder dan informasi yang berkenaan dengan teknologi agen cerdas, metodologi AUML, platform JADE, algoritma kmeans, dan pendakian gunung.

\subsubsection{Survei}

Survei terhadap 120 responden (para pendaki) untuk mengetahui apakah aplikasi pengklasteran yang akan dibuat nantinya dapat bermanfaat dan menjawab kebutuhan para pendaki.

\subsection{Analisis Kebutuhan}

Saat ini, proses pembentukan kelompok para pendaki dilakukan dengan menghubungi organisasi yang ada atau memanfaatkan media sosial, seperti grup/forum diskusi facebook, twitter dan kaskus, namun proses pengelompokan melalui media sosial tersebut dirasakan

IJCCS Vol. 9, No. 1, January 2015: $43-52$ 
kurang efektif dan efisien. Selain harus memisahkan data kelompok secara manual dan proses komunikasi yang panjang untuk menyamakan kriteria-kriteria teman satu kelompok, pendaki juga membutuhkan waktu pemrosesan yang cukup lama sampai terbentuknya sebuah kelompok pendakian. Proses pembentukan kelompok pendakian yang sedang berjalan tersebut dapat ditunjukkan pada Gambar 1.

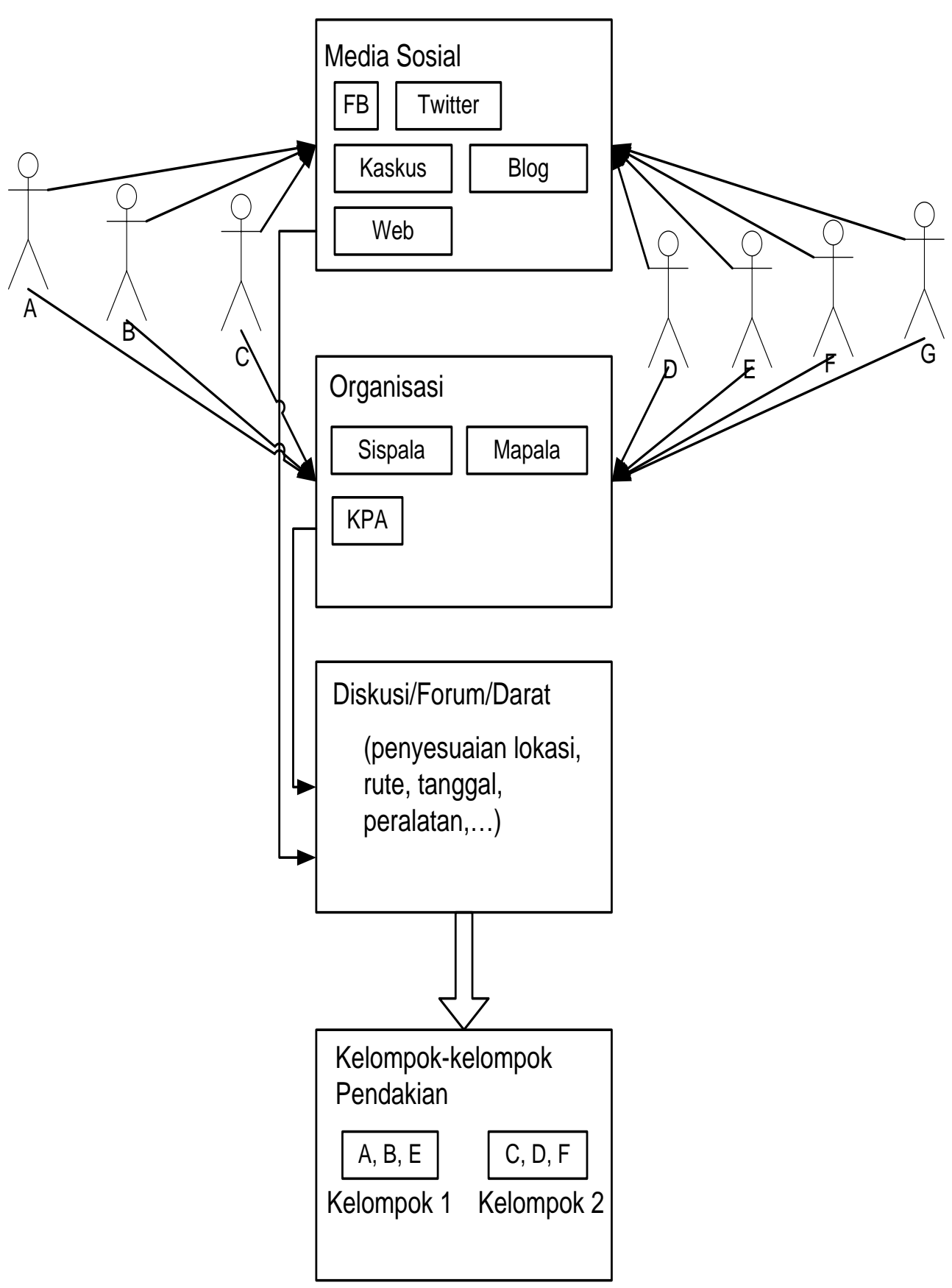

Gambar 1 Proses pembentukan kelompok pendakian 
Permasalahan yang ada ini juga diketahui dari hasil survei yang pernah dilakukan pada tahun 2012. Survei tersebut bertujuan untuk mengetahui permasalahan para pendaki dalam mencari teman pendakian. Berdasarkan 120 responden, 85\% setuju bahwa program aplikasi yang dapat mengelompokan data pendaki secara otomatis sangat dibutuhkan.

Oleh karena itu, penelitian yang diusulkan ini berupaya membangun sebuah program aplikasi yang dapat memudahkan dan mengurangi kompleksitas yang dihadapi oleh para pendaki ketika mencari kelompok pendakian. Pertama-tama para pendaki yang memiliki gunung tujuan, rute dan tanggal pendakian yang sama akan dikelompokkan terlebih dahulu, lalu dari kelompok yang memiliki kesamaan tersebut akan dikelompokkan lagi berdasarkan kemiripan kriteria, seperti usia, jenis kelamin, bahasa, pengalaman dan peralatan. Keluaran dari sistem ini adalah sebuah kelompok pendakian dengan kemiripan kriteria para pendaki. Keberagaman ini sangat penting karena tidak semua pendaki memiliki pengalaman dan peralatan. Tidak semua pendaki juga memiliki bahasa, usia dan jenis kelamin yang sama. Melalui keberagaman tersebut, para pendaki dapat saling berbagi dan melengkapi.

\subsection{Deskripsi Sistem}

Secara umum, sistem yang dibangun akan menerima masukan data para pendaki individu dan mengelompokkannya berdasarkan kemiripan kriteria seperti yang ditunjukkan pada Gambar 2.

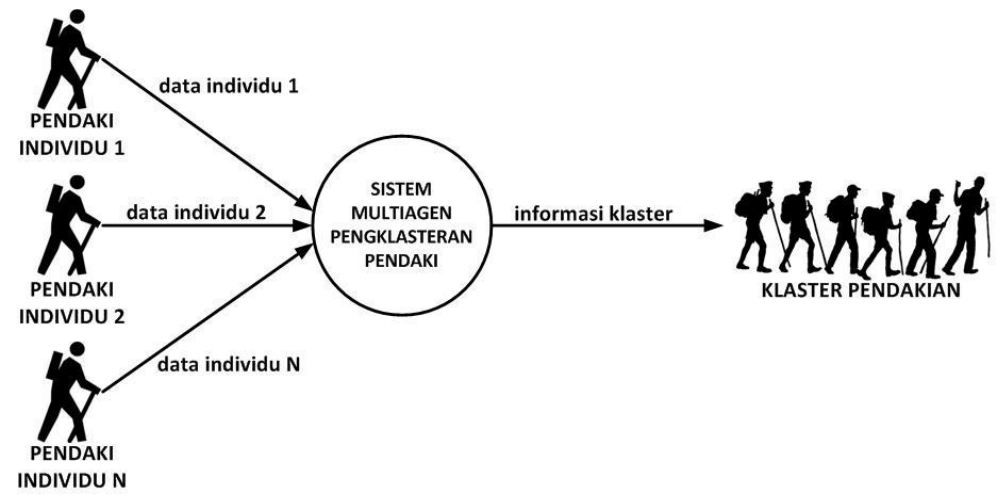

Gambar 2 Sistem multiagen pengklasteran pendaki

Secara khusus, sistem akan dibangun di atas platform JADE dengan membentuk multiagen sistem untuk melakukan tugas klastering seperti yang diusulkan oleh [4], sedangkan algoritma klastering yang digunakan adalah K-Means.

Salah satu keuntungan terbesar dari pemanfaatan multiagen adalah kemampuan negosiasi antar-agen sehingga klaster yang dihasilkan akan lebih baik. Multiagen yang dibangun terdiri dari 4 agen. Agen user akan menerima masukan jumlah klaster. Agen user juga akan berkomunikasi dengan House Keeping Agent yang secara otomatis terbentuk ketika platform JADE diaktifkan. Selanjutnya, sejumlah klaster K diciptakan oleh agen user sehingga menghasilkan sejumlah K agen klastering. Selanjutnya masing-masing agen klastering akan berinteraksi dengan agen basisdata yang akan mengirimkan satu per satu barisnya untuk dilelang oleh masing-masing agen klastering. Pemenang lelang adalah baris yang memiliki jarak terdekat dengan centroid. Perhitungan jarak terdekat menggunakan Euclidean Distance. Hasil akhir dari agen klastering adalah susunan inisial klaster terbaru dengan sejumlah baris yang menjadi anggota klasternya. Tahap berikutnya adalah mengaktifkanagen validasi. Agen validasi ini akan melakukan negosiasi antar agen klastering dengan cara kohesi/kepadatan klaster padaagen klastering dan jarak pemisah antar-klaster. Pemodelan multiagen untuk klastering tersebut dapat ditunjukkan pada Gambar 3.

IJCCS Vol. 9, No. 1, January 2015: $43-52$ 


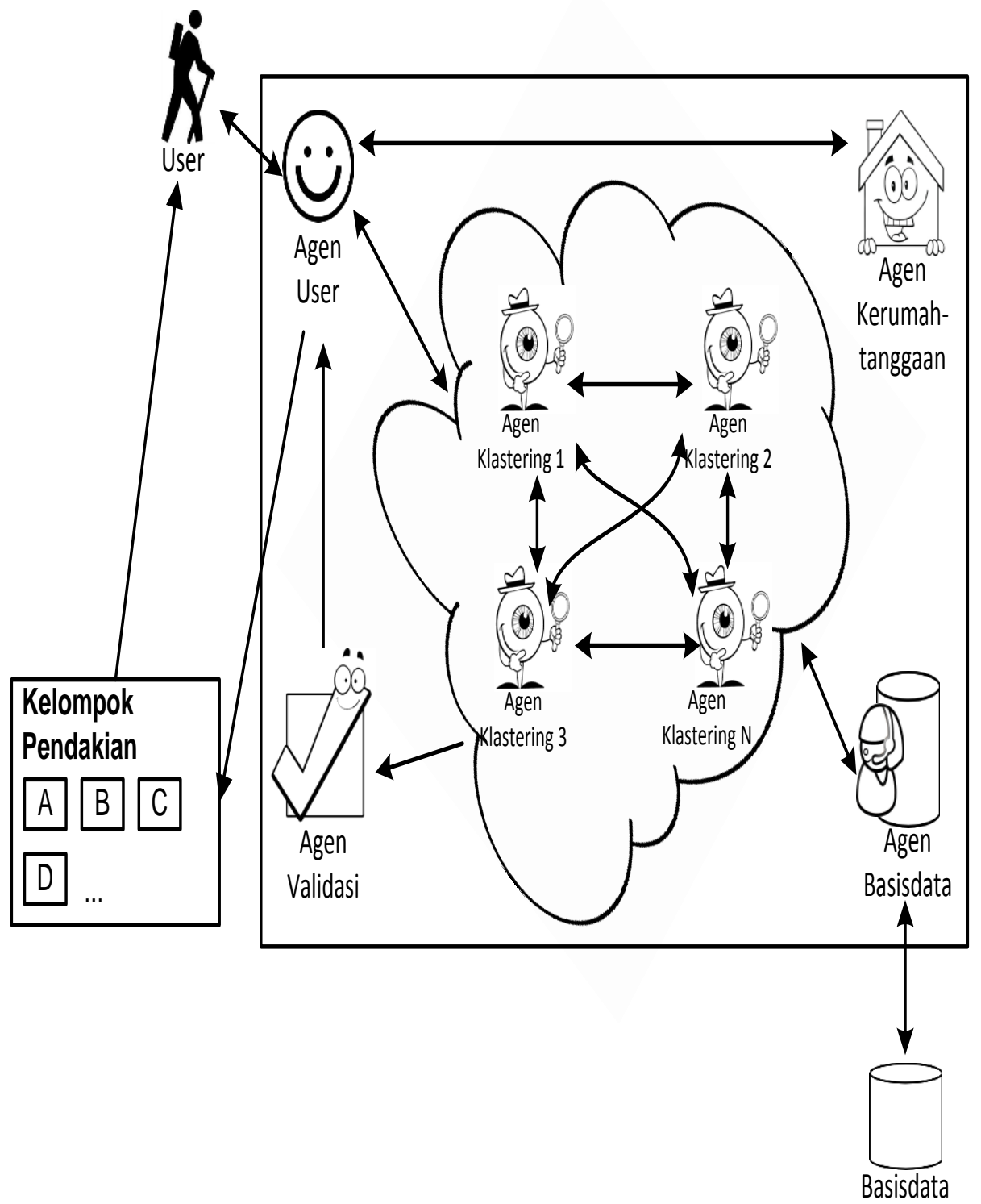

Gambar 3 Ilustrasi pemodelan agen untuk klastering data [4]

\subsection{Analisis dan Rancangan Agen}

Agen akan dianalisis dan dirancang dengan menggunakan Diagram Use Case, Agent Class Diagram, dan Sequence Diagram.

\subsubsection{Diagram Use Case}

Diagram Use Case digunakan untuk mendeskripsikan interaksi antara pengguna dan sistem.Terdapat 5 aktor dalam sistem yang dibangun, seperti yang ditunjukkan pada Gambar 4, yaitu aktor user sebagai end-user yang bertugas untuk mengirimkan data ke database, dan 4 aktor agen yang terdiri dari agen user, agen basisdata, agen klastering dan agen validasi. Hubungan antar use case terkait dengan proses manage data, spawn $k$ cluster, auction records, negotiate, receive clustering results dan retrievedata. 


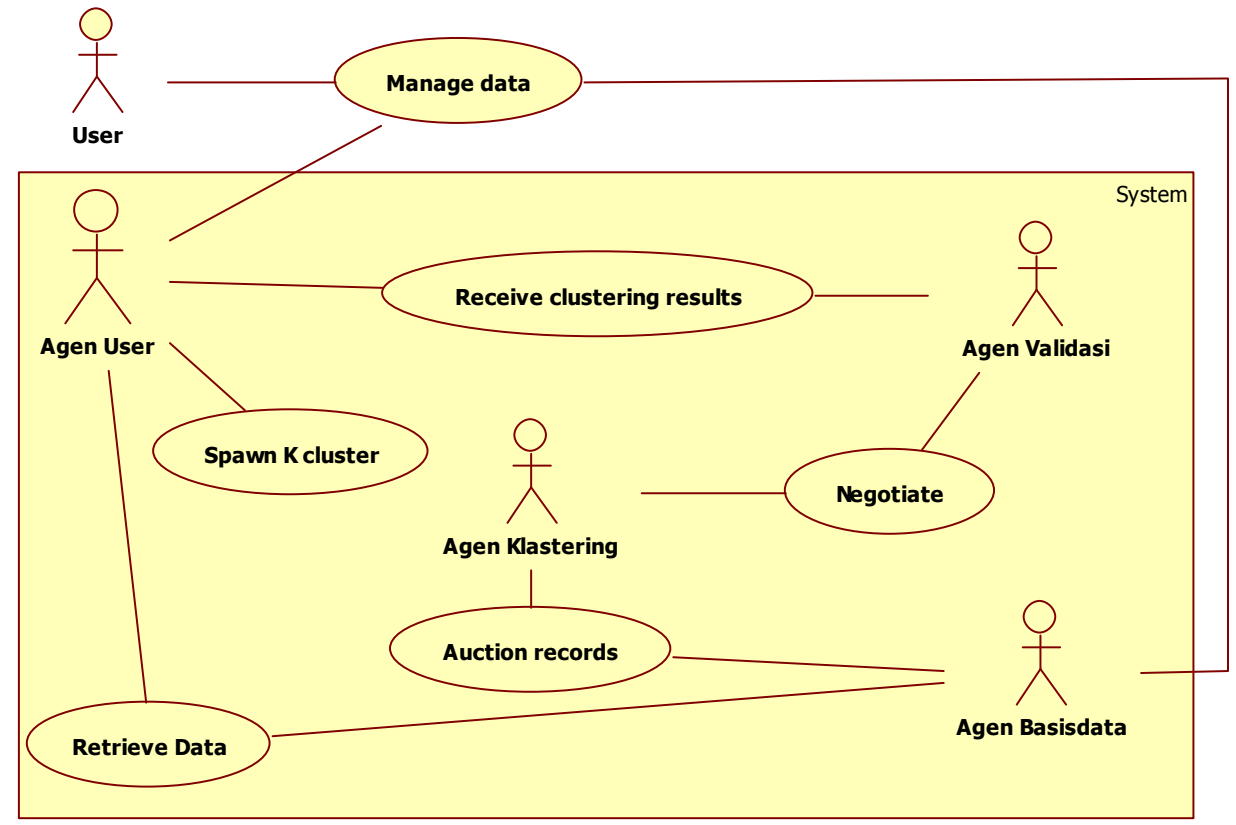

Gambar 4 Diagram Use Case

\subsubsection{Agent Class Diagram}

Agent Class Diagram mendeskripsikan jenis-jenis agen yang terdapat dalam sistem dan hubungan antar-agen tersebut. Agent Class Diagram ini dideskripsikan dalam 2 level. Level pertama adalah level konseptual yang menjelaskan hubungan antar kelas agen, seperti yang dapat ditunjukkan pada Gambar 5, sedangkan level kedua adalah level implementasi yang merincikan masing-masing kelas agen.

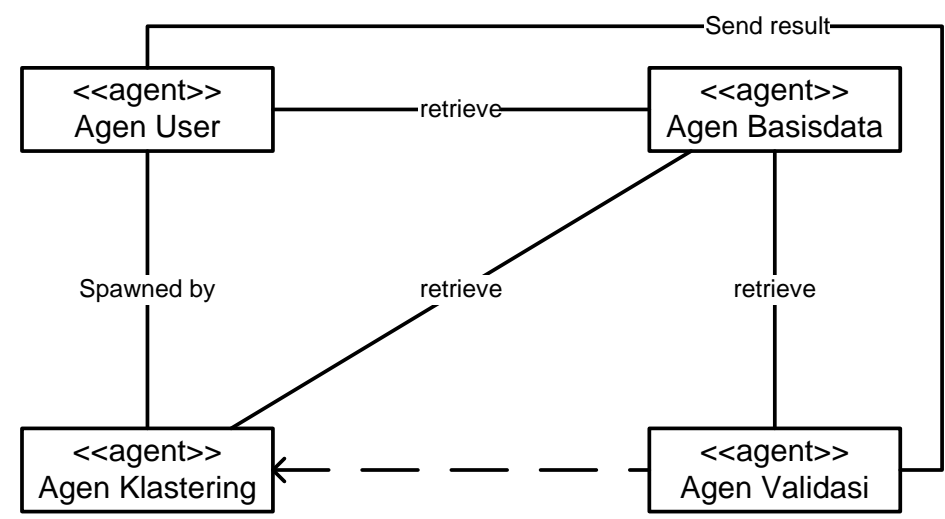

Gambar 2 Agent class diagram level konseptual

Pada Agent Class Diagram level implementasi, diagram dibagi menjadi beberapa kompartemen yang memberikan informasi role dari setiap agen, behaviour, attribute dan operation di dalam agen, serta protokol komunikasi agen.Setiap behaviour yang dibentuk oleh masing-masing agent bertujuan untuk mendukung proses pelelangan dan negosiasi. Secara sederhana, penjelasan masing-masing behaviour ditunjukkan pada Tabel 1 dan Tabel 2. 
Tabel 1 Behaviours pada proses pelelangan

\begin{tabular}{|l|l|l|l|}
\hline \multicolumn{1}{|c|}{ Agen } & \multicolumn{1}{|c|}{ Behaviour } & \multicolumn{1}{c|}{ Tipe Behaviour } & \multicolumn{1}{c|}{ Deskripsi } \\
\hline $\begin{array}{l}\text { Agen user } \\
\text { (UA) }\end{array}$ & SpawnClusteringAgent & Behaviour & Menciptakan CA sebanyak k klaster \\
\hline $\begin{array}{l}\text { Agen } \\
\text { klastering } \\
\text { (CA) }\end{array}$ & RequestFirstHikers & OneShotBehaviour & Meminta data pertama ke DA \\
\cline { 2 - 5 } & RequestPerformer & Behaviour & Meminta data satu per satu ke DA \\
\cline { 2 - 5 } & $\begin{array}{l}\text { WaitNextOneByOne- } \\
\text { HikersData }\end{array}$ & CyclicBehaviour & $\begin{array}{l}\text { Menunggu DA mengirimkan data untuk } \\
\text { dilelang. }\end{array}$ \\
\cline { 2 - 5 } & ProcessAuction-Behaviour & CyclicBehaviour & $\begin{array}{l}\text { Terima data dari DA, mencari pemenang } \\
\text { lelang. }\end{array}$ \\
\cline { 2 - 5 } & WaitAuctionToFinish & Behaviour & Menunggu proses lelang selesai. \\
\hline $\begin{array}{l}\text { Agen } \\
\text { basisdata } \\
\text { (DA) }\end{array}$ & SendFirstHikersData & CyclicBehaviour & $\begin{array}{l}\text { Mengirim data pertama ke masing-masing } \\
\text { CA }\end{array}$ \\
\cline { 2 - 5 } & PrepareAuction-Behaviour & OneShotBehaviour & $\begin{array}{l}\text { Mencari informasi CA agar bisa } \\
\text { berkomunikasi. }\end{array}$ \\
\cline { 2 - 5 } & ProcessFinish-Behaviour & CyclicBehaviour & $\begin{array}{l}\text { Menyampaikan informasi ketika selesai } \\
\text { mengirim data satu per satu. }\end{array}$ \\
\cline { 2 - 4 } & $\begin{array}{l}\text { SendOneByOneNextOfHike } \\
\text { rsData }\end{array}$ & Behaviour & Kirim data ke masing-masing CA. \\
\hline
\end{tabular}

Tabel 2 Behaviours pada proses negosiasi

\begin{tabular}{|l|l|l|l|}
\hline \multicolumn{1}{|c|}{ Agen } & \multicolumn{1}{|c|}{ Behaviour } & \multicolumn{1}{c|}{ Tipe Behaviour } & \multicolumn{1}{c|}{ Deskripsi } \\
\hline $\begin{array}{l}\text { Agen user } \\
\text { (UA) }\end{array}$ & SpawnClusteringAgent & Behaviour & Membuat VA, dan menampilkan hasilnya. \\
\hline $\begin{array}{l}\text { Agen } \\
\text { klastering } \\
\text { (CA) }\end{array}$ & ContactValidation & OneShotBehaviour & Menghubungi VA bahwa CA sudah selesai \\
\cline { 2 - 5 } & SplitterData & CyclicBehaviour & $\begin{array}{l}\text { Split CA menjadi mayor dan minor } \\
\text { (request ke VA) }\end{array}$ \\
\cline { 2 - 5 } & ProcessAuction-Behaviour & CyclicBehaviour & Menerima informasi pemenang negosiasi \\
\hline $\begin{array}{l}\text { Agen } \\
\text { validasi } \\
\text { (DA) }\end{array}$ & WaitForCA & CyclicBehaviour & Menunggu CA menyelesaikan tugasnya \\
\cline { 2 - 5 } & InitRefineCentroid & OneShotBehaviour & $\begin{array}{l}\text { Inisialisasi awal untuk menghitung } \\
\text { WGAD, BGAD, dsb }\end{array}$ \\
\hline \multirow{2}{*}{} & MainLoop & Behaviour & Proses negosiasi utama \\
\cline { 2 - 5 } & RefineCentroid & Behaviour & Perbarui nilai centroid masing-masing CA \\
\cline { 2 - 5 } & SplitCluster & Behaviour & $\begin{array}{l}\text { Buat klaster menjadi minor dan mayor } \\
\text { (inform ke CA) }\end{array}$ \\
\cline { 2 - 5 } & InRefineCentroid & Behaviour & Perbarui centroid \\
\hline
\end{tabular}

\subsubsection{Sequence Diagram}

Sequence Diagram mereperesentasikan urutan pesan antar agen, dan disusun dalam sebuah frame yang terdiri dari interaksi partisipan sepanjang rangkaian pesan. Gambar 6 menunjukkan 4 partisipan, yaitu AgenUser, AgenBasisdata, AgenKlastering dan AgenValidasi, dimana mereka akan saling berkirim pesan menggunakan performatif yang ada. 


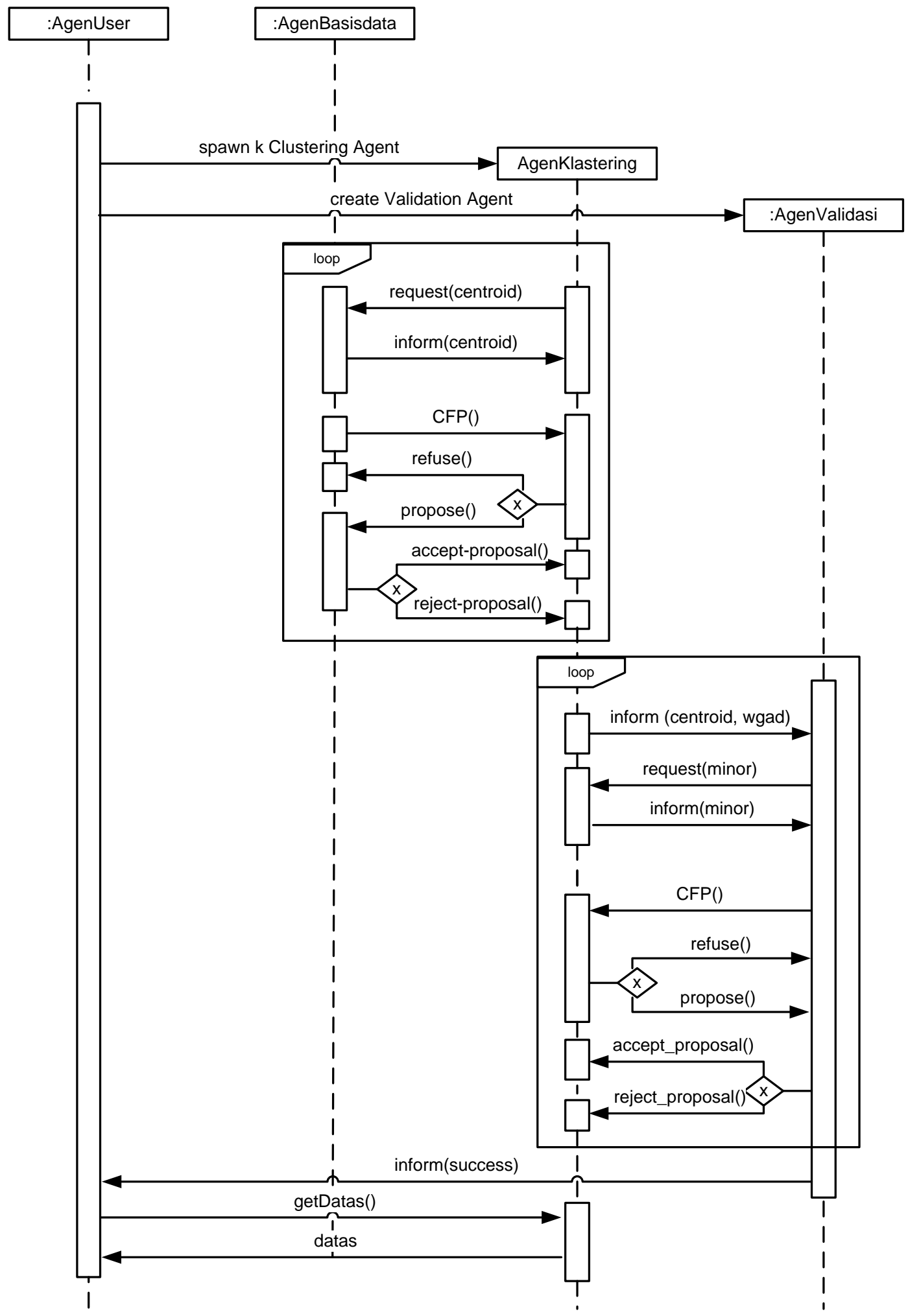

Gambar 6 Sequence Diagram 


\section{HASIL DAN PEMBAHASAN}

Keluaran dari sistem multiagen yang telah diimplementasikan untuk melakukan klastering dibagi menjadi 2 tahapan. Tahap pelelangan menghasilkan jumlah klaster yang sesuai dengan jumlah klaster yang diinginkan oleh user, sedangkan pada tahap negosiasi, agen akan menciptakan klaster yang baru jika terdapat data outliers di dalam database.

Pengujian hasil klastering seperti algoritma klastering K-Means dengan tipe unsupervised ini hanya terbatas pada faktor internal klaster. Metrik evaluasi dari unsupervised biasanya dibagi menjadi 2 jenis, yaitu perhitungan nilai kohesi/kepadatan dalam klaster (WGAD) dengan cara menghitung kedekatan masing-masing obyek dalam 1 klaster, dan dengan menghitung jarak pemisah antar klaster (BGAD). Hasil yang terbaik diperoleh jika klaster tersebut memiliki nilai WGAD yang rendah dan nilai BGAD yang tinggi. Pengujian dilakukan dengan menguji 10 data, 100 data dan 200 data dengan jumlah klaster yang berbeda-beda seperti yang ditunjukkan pada Tabel 3 .

Tabel 3 Hasil Perbandingan nilai WGAD dan BGAD

\begin{tabular}{|c|c|c|c|}
\hline Jumlah Data & Jumlah K & WGAD & BGAD \\
\hline \multirow{4}{*}{10} & 3 & 5.5153 & 33.0343 \\
\cline { 2 - 4 } & 4 & 4.0191 & 53.5251 \\
\cline { 2 - 4 } & 5 & 2.6945 & 68.2971 \\
\cline { 2 - 4 } & 6 & 2.3033 & 81.7922 \\
\hline \multirow{4}{*}{100} & 7 & 1.7993 & 93.7077 \\
\cline { 2 - 4 } & 3 & 4.9627 & 34.0765 \\
\cline { 2 - 4 } & 4 & 3.7359 & 48.3873 \\
\cline { 2 - 4 } & 5 & 3.3254 & 63.0736 \\
\hline \multirow{4}{*}{200} & 7 & 3.0556 & 78.4287 \\
\cline { 2 - 4 } & 3 & 2.8702 & 83.1778 \\
\cline { 2 - 4 } & 4 & 4.0934 & 32.0253 \\
\cline { 2 - 4 } & 5 & 3.6840 & 45.8600 \\
\cline { 2 - 4 } & 6 & 3.4653 & 67.9918 \\
\hline \multirow{5}{*}{} & 7 & 3.1877 & 83.8066 \\
\hline
\end{tabular}

Berdasarkan evaluasi hasil klastering terhadap proses pelelangan dan negosiasi, dapat dilihat bahwa semakin besar jumlah klaster, maka nilai kohesi/jarak baris ke titik pusat klaster semakin kecil, dan jarak pemisah antar-klaster semakin besar.

\section{KESIMPULAN}

Berdasarkan uraian hasil dan pembahasan dapat disimpulkan bahwa :

1. Sensitivitas dari pengenalan outlier sangat tinggi, sehingga nilai WGAD cenderung lebih besar dari wgadtreshold dan bgad cenderung lebih kecil dari bgad treshold,

2. Hasil pengujian terhadap 10,100 , dan 200 data terhadap beberapa nilai $\mathrm{K}$ menunjukkan bahwa nilai WGAD pada jumlah klaster yang banyak lebih kecil dibandingkan jumlah klaster yang sedikit, sedangkan nilai BGAD memiliki nilai yang lebih kecil untuk jumlah klaster yang sedikit dan semakin besar untuk jumlah klaster yang semakin banyak. 


\section{SARAN}

Penentuan titik pusat klaster awal pada penelitian ini masih menggunakan $\mathrm{K}$ data pertama sehingga ada kemungkinan mempengaruhi hasil klaster secara keseluruhan. Penelitian selanjutnya dapat membandingkan hasil klaster yang dihasilkan dengan penentuan titik pusat klaster awal yang lebih baik sehingga nilai kohesi (WGAD) lebih kecil dan jarak antar-klaster lebih besar (BGAD).

\section{DAFTAR PUSTAKA}

[1] Davidson, D., 2006, A Mountain Feeling: The Narrative Construction of Meaning and Self Through a Commitment to Mountaineering in Aotearoa/New Zealand, Disertasi, Monash University.

[2] Holzen, 2011, Trail Classification, http://www.indovolcano.com/classification/, diakses tgl 12 November 2013.

[3] Weber, K., 2001, Outdoor Adventure Tourism: A Review of Research Approaches, Annals of Tourism Research, No. 28, Vol. 2, hal. 360-377.

[4] Chaimontree, S., Atkinson, K., dan Coenen, F., 2011, A Multi-Agent Based Approach to Clustering: Harnessing The Power of Agents, Springer Berlin Heidelberg, Germany. 